\title{
FCGR2A wt Allele
}

National Cancer Institute

\section{Source}

National Cancer Institute. FCGR2A wt Allele. NCI Thesaurus. Code C51390.

Human FCGR2A wild-type allele is located within $1 \mathrm{q} 23$ and is approximately $14 \mathrm{~kb}$ in length. This allele, which encodes low affinity immunoglobulin gamma Fc region receptor II-a protein, plays a role in receptor signal transduction and may be involved in collagenmediated platelet activation. 